\title{
Early adversity and adult delinquency: the mediational role of mental health in youth offenders
}

\author{
Adversidade precoce e delinquência na idade adulta: \\ o papel mediador da saúde mental em jovens ofensores
}

Miguel Basto-Pereira (https://orcid.org/0000-0002-2929-1775) ${ }^{1}$

Ângela da Costa Maia (https://orcid.org/0000-0003-1343-9699) ${ }^{2}$

${ }^{1}$ William James Center for Research, ISPA - Instituto Universitário. R. Jardim do Tabaco 34. 1149-041 Lisboa Portugal.

${ }^{2}$ Psychology Research Centre, School of

Psychology, University of Minho, Portugal.

\begin{abstract}
This research explores the mediational role of mental health in the relationship between early adverse experiences and current self-reported delinquency in young adults with past juvenile justice involvement. Seventy-five young adults with official records of juvenile delinquency in 2010/2011 filled out our protocol in 2014/2015 including the Adverse Childhood Experiences (ACE) questionnaire, the Brief Symptom Inventory, and the D-CRIM questionnaire (evaluating delinquency). The global level of adverse experiences during childhood and adolescence was related to mental health problems and self-reported delinquency in young adulthood, while psychopathological symptoms were also related to current self-reported delinquency. The mental health indicator partially mediated the link between early adversity and current self-reported offending in individuals with past juvenile justice involvement. Our results are in line with previous psychological and neurobiological approaches and highlight the importance of mental health services in youth offender rehabilitation. Future directions for research are provided.
\end{abstract}

Key words Mental health, Childhood adverse experiences, Juvenile delinquency, Adult offending, Juvenile justice involvement
Resumo Esta pesquisa explora o papel mediador da saúde mental na relação entre experiências adversas precoces e delinquência autorreportada em jovens adultos com historia de envolvimento no sistema de justiça juvenil. Setenta e cinco jovens adultos com registros de delinquência juvenil em 2010/2011 preencheram o protocolo em 2014/2015, incluindo o Questionário de Experiências Adversas na Infância, o Inventário de Sintomas Psicopatológicos e o D-CRIM (que avalia a delinquência). O nivel global de experiências adversas na infância e adolescência associou-se tanto a problemas de saúde mental como à delinquência autorreportada em jovens adultos, os sintomas psicopatológicos estiveram também associados à delinquência juvenil no presente. $O$ indicador de saúde mental parcialmente mediou a relação entre adversidade precoce e o nivel atual de delinquência em indivíduos com história de envolvimento no sistema de justiça juvenil. Os nossos resultados estão em linha com abordagens psicológicas e neurológicas prévias e salientam a importância dos serviços de saúde mental na reabilitação de jovens ofensores. Direções futuras são apresentadas.

Palavras-chave Saúde mental, Experiências adversas na infância, Delinquência juvenil, Comportamento criminal adulto, Envolvimento no sistema de justiça juvenil 


\section{Introduction}

Worldwide research shows that the majority of juvenile delinquents were victims of abuse, neglect or serious household dysfunction during childhood $^{1,2}$ and those experiences have been highlighted as important promotors of offending persistence in juvenile delinquents ${ }^{1,3}$. From a neurobiological point of view, continued exposure to high stress situations could lead to the dysregulation of the biological response to stress situations (e.g. abnormal release of cortisol, serotonin), which affects the brain development including the areas responsible for interpreting external stimuli (cognitive processing) and regulating negative emotions ${ }^{4}$. Lack of self-control, depression and anxiety are some of the consequences found in several empirical studies ${ }^{5}$, leading to serious psychological dysfunction and consequently, to serious behavioral problems, including anti-social behavior ${ }^{6}$.

Simultaneously, children living in violent or distressed family environments could develop insecure attachment, affecting child development and relational skills, including empathy and social competence ${ }^{7}$. Those competencies, strictly related to adaptive psychological functioning, are tremendously important for prosocial behavior ${ }^{4,7}$. Within these relevant frameworks, the first impact of child and adolescent adversity is on psychological functioning, particularly promoting dysfunctional interpersonal interactions during the development process, which continuously affects the values and beliefs about the self, others, and the world. Past longitudinal studies conducted in large samples have found significant relationships between the number of different adverse experiences and future mental health problems ${ }^{8}$, while other studies found that mental health played a major role on future criminal behavior?.

More recently, a Portuguese research team found that 7 out of 10 self-reported adverse experiences (emotional abuse, physical abuse, sexual abuse, emotional neglect, parental separation or divorce, witnessing domestic violence, incarcerated household members) were significantly more prevalent amongst individuals with past juvenile justice system involvement, as compared to others in the community ${ }^{10}$. Moreover, the same type of correlations, between mental health indicators and childhood adverse experiences, were found among young adults with an official history of juvenile delinquency ${ }^{10,11}$, which raises the following hypothesis: are mental health problems one of the mediators between serious adversity and offending? This question is much more relevant in young adults with past juvenile justice involvement, not only because they are more common victims of serious adverse experiences $^{1}$ or in higher risk of recidivism, but also because it is particularly during young adulthood that offending achieves it's peak ${ }^{12}$. Moreover, politically it is tremendously important to understand which variables are capable of promoting desistence from crime in youths with juvenile justice involvement. In this regard, our aim is to explore whether mental health problems are a mediator between early adversity and persistence in crime in young adults with an official history of juvenile delinquency.

\section{Method}

\section{Participants and procedure}

The current study includes 75 young adults with juvenile sentences in 2010/2011 for crimes committed between the age of 12 to 15 years old. The sample was collected in 2014/2015 through 28 Portuguese Juvenile Justice or Probation offices where these young adults have finished or were serving non-custodial sentences following convictions in juvenile courts or in adult courts (for new crimes committed after 15 years of age). Young adult participants who met the inclusion criteria were invited to participate by the juvenile justice or probation office professionals. Overall, 219 potential participants were identified, $55.4 \%$ were ineligible to participate because a large set of reasons, including not attending to the juvenile justice or probation offices three (or more) times (where they should be officially invited to participate), had emigrated, or has been transferred to another justice office. From the participants initially tracked, only $9.6 \%$ refused to participate. Youths who agreed to participate were informed about the aims of this study, signed the informed consent, and filled out the protocol (filling time around 30-35 minutes). The mean age of our sample was $20.20(\mathrm{SD}=1.56)$ and $92 \%$ of the participants are young adult males $(n=69)$. The University of Minho Ethics Committee and the General Direction of Prison and Probation Services of the Ministry of Justice authorized this study. Detailed information about demographics is presented in Table 1. 
Adverse Childhood Experiences (ACE) study questionnaire. The ACE questionnaire is a self-report measure evaluating serious adverse experiences during the first 18 years of life. This questionnaire includes 53 items with dimensions related to physical abuse, sexual abuse, emotional abuse, physical neglect, emotional neglect and household dysfunction including domestic violence, substance abuse, mental illness or incarceration in the household or parental divorce. Abuse, neglect and domestic violence dimensions were evaluated according to their frequency from " $0=$ Never" to " $4=$ Too Often" while the remaining experiences were evaluated through their presence (Yes/ No). The global level of ACE was used in this study. The Portuguese and original versions showed appropriate psychometric characteristics ${ }^{13,14}$.

Brief Symptom Inventory (BSI). This inventory is a self-report measure evaluating psychological distress and psychiatric symptoms ${ }^{15,16}$. The BSI is considered a good indicator of general mental health state, with good temporal stability and good discriminative proprieties, namely regarding to the comparison between general population and patients followed in psychiatric services ${ }^{17,18}$. This questionnaire includes 53 items about current psychological symptoms, through a Likert scale each participant classifies how often symptoms have occurred in the last 7 days. The questionnaire includes nine symptom dimensions (e.g., depression, anxiety, hostility) and three general dimensions (global severity index, positive symptom index and the positive symptom total). The current study used the global severity index as an indicator of current mental health problems, this dimension showed an excellent level of reliability with a Cronbach $=.96$. The original and the Portuguese versions of this questionnaire showed appropriate psychometric proprieties $^{15,16}$.

Self-Report questionnaire for measuring delinquency and crime (D-CRIM). The D-CRIM questionnaire $^{2}$ evaluates the presence of criminal behaviors in the last year and during the lifetime. Each participant classifies the presence (No/Yes) of 12 different criminal behaviors (theft, robbery,

driving without license, domestic violence, aggression, rape, drug trafficking, illegal carrying of a firearm, homicide, family violence, blackmail, and property damage) committed in the last twelve months and throughout life. The original version showed appropriate psychometric proprieties for the adult Portuguese population.

\section{Data analysis}

All the variables included in the analysis were described and correlations among them were tested (Pearson correlations for the relationship between quantitative variables, Phi coefficients for the relationship between categorical variables and Point bi-serial for the relationship between categorical and quantitative variables) using SPSS 23 (SPSS; Version 23.0, Chicago, IL, USA). The PROCESS macro for SPSS was used to test the mediation role of mental health problems on the link between childhood or adolescent adversity and current self-reported delinquency ${ }^{19}$. The significance of direct and indirect effects was estimated using the bootstrapping bias corrected percentile method with 1000 resamples.

\section{Results}

Descriptive data about each psychopathologic symptom, general symptom index, and the prevalence of each childhood adverse experience is provided in Table 2.

Pearson correlations showed that all the potential predictors were correlated with the hypothesized outcome (D-CRIM 12M). The largest correlation was established between Total score of Adverse Childhood Questionnaire (ACE) and self-reported delinquency in the last 12 months $(r=.37, \mathrm{p}<.001)$. Descriptive statistics and matrix correlation is presented in Table 3.

Following the procedure of mediation anal$\mathrm{ysis}^{19}$, we tested the predictive ability of adverse childhood and adolescent experiences on the D-CRIM ( $\beta=.37$; CI $95 \%[.15-59])$, the predictive ability of ACE on the global severity inventory ( $\beta=.33$; CI $95 \%$ [.15-59]), and finally, the global severity index (GSI) as a predictor of the D-CRIM ( $\beta=.23$, CI $95 \%$ [.01-.45]), as presented in Figure 1.

Because the three regressions models were found to be significant we proceed to mediation analysis using the PROCESS macro. The significant indirect effect of GSI on the relationship between ACE and D-CRIM 12M was found to 
Table 1. Sociodemographic characteristics of ORJC sample.

\begin{tabular}{|c|c|c|}
\hline \multirow{2}{*}{ Characteristics } & \multicolumn{2}{|c|}{ ORJC $(\mathrm{N}=75)$} \\
\hline & $\mathbf{n}$ & $\%$ \\
\hline \multicolumn{3}{|l|}{ Sex } \\
\hline Male & 69 & $92.00 \%$ \\
\hline Female & 6 & $8.00 \%$ \\
\hline \multicolumn{3}{|l|}{ Age Brackets } \\
\hline $18-20$ & 45 & $60.00 \%$ \\
\hline $21-23$ & 28 & $37.33 \%$ \\
\hline $24-26$ & 2 & $2.67 \%$ \\
\hline \multicolumn{3}{|l|}{ Ethnicity/race } \\
\hline Majority & 44 & $58.67 \%$ \\
\hline Minority & 31 & $41.33 \%$ \\
\hline \multicolumn{3}{|l|}{ Residential area } \\
\hline Rural & 15 & $20.00 \%$ \\
\hline Urban & 60 & $80.00 \%$ \\
\hline \multicolumn{3}{|l|}{ Occupation } \\
\hline Worker & 18 & $24.00 \%$ \\
\hline Student & 14 & 18.67 \\
\hline Student-Worker & 1 & $1.33 \%$ \\
\hline Without occupation & 42 & $56.00 \%$ \\
\hline
\end{tabular}

be significant $(\beta=.07 \mathrm{CI} 95 \%[.01 ; .18])$, with an effect size of $\kappa^{2}=.06$ CI 95\% [.01; .18], indicating that the current mental health problems mediate the relationship between ACE and D-CRIM 12 . The full model explained $18.24 \%$ of the variance, $\mathrm{F}(2,72)=8.03, p<.001$. However, because the direct effects of ACE on D-CRIM is still significant in the presence of GSI $(\beta=.29$ CI $95 \%$ $[.07 ; .52])$, this mediation is only partial.

\section{Discussion}

This is an exploratory study, to the best of our knowledge, this is the first study to test the mediational role of mental health on the link between early adversity and adult crime in individuals with a history of juvenile delinquency. Our study supports that early adversity exposure, such as abuse, neglect or serious household dysfunction, are related with persistence in crime and one of these paths is mental health problems.

Some points could be noted from this research. First, our study supports the previous links found between early adversity and mental health problems ${ }^{8}$, as well as between mental

Table 2. Descriptive statistics for BSI and ACE dimensions.

\begin{tabular}{lccclcc}
\hline \multicolumn{1}{c}{ BSI Dimensions } & Scale & M & SD & ACE Dimensions & n & \% \\
\hline Somatization & $0-4$ & 0.35 & 0.46 & Emotional Abuse & 22 & $29.30 \%$ \\
Obsessive-compulsivity & $0-4$ & 0.88 & 0.61 & Physical Abuse & 24 & $32.00 \%$ \\
Interpersonal sensitivity & $0-4$ & 0.70 & 0.80 & Sexual Abuse & 30 & $40.00 \%$ \\
Depression & $0-4$ & 0.71 & 0.71 & Emotional Neglect & 33 & $44.00 \%$ \\
Anxiety & $0-4$ & 0.57 & 0.52 & Physical Neglect & 19 & $25.30 \%$ \\
Hostility & $0-4$ & 0.96 & 0.79 & Parental Separation / Divorce & 39 & $52.00 \%$ \\
Phobic anxiety & $0-4$ & 0.31 & 0.44 & Witnessing domestic violence & 17 & $22.70 \%$ \\
Paranoid ideation & $0-4$ & 1.29 & 0.78 & Household substance abuse & 31 & $41.30 \%$ \\
Psychoticism & $0-4$ & 0.71 & 0.75 & Mental illness in the household & 7 & $9.30 \%$ \\
General Symptom Index & $0-4$ & 0.72 & 0.54 & Incarcerated household members & 21 & $28.00 \%$ \\
\hline
\end{tabular}

Table 3. Correlation matrix.

\begin{tabular}{lrrrrrrr}
\hline & M & SD & $\begin{array}{c}\text { Race/ } \\
\text { Ethnicity }\end{array}$ & Age & ACE & GSI & DCRIM 12M \\
\hline Gender & - & - & $-0.25^{*}$ & -0.07 & -0.09 & 0.11 & -0.10 \\
Race /Ethincity & - & - & & -0.05 & -0.05 & -0.06 & -0.06 \\
Age & 20.20 & 1.58 & & & 0.00 & 0.11 & 0.18 \\
ACE & 24.97 & 14.60 & & & & $0.33^{* *}$ & $0.37^{* *}$ \\
GSI - Total & 0.72 & 0.54 & & & & & $0.32^{* *}$ \\
DCRIM 12 & 1.59 & 1.82 & & & & & \\
\hline
\end{tabular}

Note. No missing data. ACE $=$ Total score of Adverse Childhood Questionnaire; GSI= Global Severity Index/ Overall psychological distress; DCRIM $12 \mathrm{M}=$ Self-reported in the last 12 months.

$\dagger \mathrm{p}<.1 ;{ }^{*} \mathrm{p}<.05 ;{ }^{* *} \mathrm{p}<.001$. 
Figure 1. Standardized regression coefficients for the mediating model.

$\dagger \mathrm{p}<.1 ;{ }^{*} \mathrm{p}<.05 ;{ }^{* *} \mathrm{p}<.001$.

health problems and adult offending ${ }^{20}$. Second, this study advances knowledge about the role of mental health problems as one of the mediators between early adversity and crime. Third, our results could be explained in the light of previous psychological and neurobiological approaches, supporting the view that chronic exposure to adverse experiences heighten the state of alarm which affects psychological functions, and consequently leads to dysfunctional interpersonal skills and interactions, promoting and reinforcing dysfunctional and anti-social cognitive patterns (e.g., hostile attribution bias) and behaviors, including offending ${ }^{4,6}$. Therefore, if mental health is a mediator between child and adolescent toxic environments and persistence in crime during adulthood, as pointed out in this study, the juvenile justice systems should improve the accessibility and quality of mental health services, which may help to diminished recidivism. Moreover, primary and secondary interventions are recommended. Child Protective Services should provide a full screening for adverse childhood experiences, beyond physical and sexual abuse, thereby, helping to prevent delinquency in the first place, and other major problems associated to serious adverse experiences.

This research contains limitations that should be acknowledged. Despite the high number of participants per variable, this study has a small sample size, and generalizations should be made carefully. Another important limitation is the lack of a prospective longitudinal design to con- firm the causality effects between variables. This is an exploratory study, future studies should test this mediation model in larger samples and with prospective longitudinal designs. Third, only $8 \%$ to $10 \%$ of participants in this study were female, nonetheless this percentage is very close to the Portuguese juvenile justice conviction $\mathrm{s}^{21}$.

Finally, legal, social, psychological, and family dimensions are important to explain juvenile offending and recidivism ${ }^{22}$; however, this study has, for the first time, specifically focused on mental health state as a mediational link between childhood adverse experiences and persistence in crime in young adults with a history of juvenile delinquency. Future studies should explore other mediators explaining this relationship.

\section{Disclosure statement}

The author(s) declared no potential conflicts of interest with respect to the research, authorship, and/or publication of this article.

\section{Collaborations}

M Basto-Pereira worked on the conception, design, analysis, interpretation of data, drafting the article and approval of the version to be published and ARPC Maia worked on analysis, interpretation of data, revising the article critically and approval of the version to be published. 


\section{Acknowledgments}

We would like to thank the reviewers for their helpful suggestions. In addition, the authors deeply appreciate the support provided by the professionals of the Direção-Geral de Reinserção e Serviços Prisionais. The first author was supported by a doctoral grant from the Foundation of Science and Technology (FCT) - Portugal.

\section{References}

1. Baglivio MT, Epps N, Swartz K, Huq MS, Sheer A, Hardt NS. The prevalence of adverse childhood experiences (ACE) in the lives of juvenile offenders. Journal of Juvenile Justice 2014; 3:1-23.

2. Basto-Pereira M, Miranda A, Ribeiro S, Maia A. The psychometric properties of a questionnaire for measuring delinquency and crime (D-CRIM). In: Sánchez M, Sánchez T., organizers. Avances en Psicología Clínica, 2015. Granada: Asociación Española de Psicología Conductual (AEPC); 2017. p. 856-867.

3. Fox BH, Perez N, Cass E, Baglivio MT, Epps N. Trauma changes everything: Examining the relationship between adverse childhood experiences and serious, violent and chronic juvenile offenders. Child Abuse Neglect 2015; 46:163-173.

4. Cicchetti D, Toth SL. Child maltreatment. Annu Rev Clin Psycho 2005; 1:409-438.

5. Pinto RJ, Maia AC. Psychopathology, physical complaints and health risk behaviors among youth who were victims of childhood maltreatment: A comparison between home and institutional interventions. Child Youth Serv Rev 2013; 35(4):603-610.

6. Lee V, Hoaken P. Cognition, emotion, and neurobiological development: mediating the relation between maltreatment and aggression. Child Maltreatment 2007; 12(3):281-298.

7. Paterson R, Moran G. Attachment theory, personality development and psychotherapy. Clin Psychol Rev 1988; 8:611-636.

8. Schilling EA, Aseltine RH, Gore S. The impact of cumulative childhood adversity on young adult mental health: Measures, models, and interpretations. Soc Sci Med 2008; 66(5):1140-1151.

9. Vinkers DJ, de Beurs E, Barendregt M, Rinne T, Hoek HW. The relationship between mental disorders and different types of crime. Crim Behav Ment Heal 2011; 21(5):307-320.

10. Basto-Pereira M, Miranda A, Ribeiro S, Maia. Growing up with adversity: From juvenile justice involvement, to criminal persistence and psychosocial problems in young adulthood. Child Abuse Neglect 2016; 62:63-75.

11. Basto-Pereira M, Maia A. Persistence in crime in young adults with a history of juvenile delinquency: The role of mental health and psychosocial problems. Int J Ment Health Addict 2018; 16(2):496-506.

12. Stolzenberg L, D'Alessio, SJ. Co-offending and the age-crime curve. J Res Crime Delinq 2008; 45:65-86.
This study was conducted at the Psychology Research Centre, School of Psychology, University of Minho, and supported by the Portuguese Foundation for Science and Technology and the Portuguese Ministry of Science, Technology and Higher Education, through the national funds (PIDDAC). The first author has revised the manuscript in ISPA - Instituto Universitário.

13. Felitti V, Anda R, Nordenberg D, Williamson, Spitz A, Edwards V, Koss MP, Marks J. Relationship of childhood abuse and household dysfunction to many of the leading causes of death in adults. Am J Prev Med 1998; 14(4):245-258.

14. Pinto R, Correia L, Maia AC. Assessing the reliability of retrospective reports of adverse childhood experiences among adolescents with documented childhood maltreatment. J Fam Violence 2014; 29:431-438.

15. Derogatis LR. BSI Brief Symptom Inventory: Administration, scoring, and procedure manual. $4^{\text {th }}$ ed. Minneapolis: National Computers Systems; 1993

16. Canavarro C. Inventário de sintomas psicopatológicos - BSI [Brief Symptom Inventory - BSI]. In: Simões MR, Gonçalves MM, editors. Testes e provas psicológicas em Portugal. Braga: APPORT/SHO; 1999. p. 95-109.

17. Canavarro MC. Inventário de Sintomas Psicopatológicos: Uma revisão crítica dos estudos realizados em Portugal [Brief Symptom Inventory/BSI - A critical Review of studies conducted in Portugal]. In: Simões M, Machado C, Gonçalves M, Almeida L, editors. Avaliação psicológica: Instrumentos validados para a população Portuguesa. Coimbra: Quarteto Editora; 2007. p. 305-331.

18. Derogatis LR. The Brief Symptom Inventory. Baltimore: Clinical Psychometric Research; 1975.

19. Hayes AF. Introduction to mediation, moderation, and conditional process analysis: A regression-based perspective. New York: The Guilford Press; 2013.

20. Schubert CA, Mulvey EP, Glasheen C. Influence of mental health and substance use problems and criminogenic risk on outcomes in serious juvenile offenders. J Am Acad Child Psy 2011; 50(9):925-937.

21. Portugal. Ministry of Justice. Directorate-General of Social Rehabilitation (DGRS). Auto-avaliação e Relatório de Atividades - DGRS 2011 [DGRS - Self-assessment and Activity Report - 2011]. Lisboa: DGRSP; 2012.

22. Farrington DP, Maria MT, JW Coid. Development of adolescence-limited, late-onset, persistent offenders from age 8 to age 48. Aggress Behav 2009; 35(2):150163.

Artigo apresentado em 27/04/2017

Aprovado em 29/01/2018

Versão final apresentada em 31/01/2018 